\title{
PENGARUH FAKTOR JUMLAH PRODUKSI DAN BIAYA TENAGA KERJA TERHADAP LABA USAHA TELUR ASIN UD. MARDLOTILLAH SALTY EGG DESA BAMBANG KECAMATAN TURI KABUPATEN LAMONGAN
}

\author{
*(Evi Fitrotun Najiah \\ Prodi Manajemen, Fakultas Ekonomi, Universitas Islam Lamongan \\ Jl. Veteran No.53A Lamongan \\ Telp. ( 0322 ) 324706, Faks. ( 0322 ) 324706 \\ Email :jpim.unisla@gmail.com
}

\begin{abstract}
ABSTRAK
Rumusan masalah dari penelitian ini adalah (1)Apakah jumlah produksi dan biaya tenaga kerja berpengaruh secara parsial terhadap laba usaha telur asin UD. Mardlotillah Salty Egg Desa Bambang Kec. Turi Kab. Lamongan?.(2)Apakah jumlah produksi dan biaya tenaga kerja berpengaruh secara simultan terhadap laba usaha telur asin UD. Mardlotillah Salty Egg Desa Bambang Kec. Turi Kab. Lamongan?.(3) Variabel manakah diantara jumlah produksi dan biaya tenaga kerja yang lebih dominan berpengaruh terhadap laba usaha telur asin UD. Mardlotillah Salty Egg Desa Bambang Kec. Turi Kab. Lamongan?. Hipotesis dari penelitian ini adalah (1) diduga jumlah produksi dan biaya tenaga kerja berpengaruh secara parsial terhadap tingkat laba usaha telur asin UD. Mardlotillah Salty Egg Desa Bambang Kec. Turi Kab. Lamongan.(2)diduga jumlah produksi dan biaya tenaga kerja berpengaruh secara simultan terhadap tingkat laba usaha telur asin UD. Mardlotillah Salty Egg Desa Bambang Kec. Turi Kab. Lamongan.(3)Diduga jumlah produksi berpengaruh signifikan terhadap tingkat laba usaha telur asin UD. Mardlotillah Salty Egg Desa Bambang Kec. Turi Kab. Lamongan. Dari hasil penelitian didapatkan koefisien korelasi parsial antara laba dan jumlah produk adalah 0,977. Kekuatan hubungan antara laba dan jumlah produk ketika variabel lainnya konstan adalah sangat kuat koefisien korelasi parsial antara laba dan biaya tenaga kerja adalah 0,973. Variabel jumlah produk $\left(X_{1}\right)$ secara parsial mempunyai pengaruh signifikan terhadap laba $(Y)$ dengan $t_{\text {hitung }}$ untuk variabel jumlah produk lebih besar dari $t$ tabel yaitu sebesar 35,151 > 2,00172. variabel biaya tenaga kerja $\left(\mathrm{X}_{2}\right)$ secara parsial mempunyai pengaruh signifikan terhadap laba $(Y)$ dengan $t$ hitung untuk variabel biaya tenaga kerja lebih besar dari $t_{\text {tabel }}$ yaitu sebesar 32,390 > 2,00172. Variabel jumlah produk dan biaya tenaga kerja secara simultan berpengaruh signifikan terhadap laba dan $F_{\text {hitung }}$ lebih besar dari $F_{\text {tabel }}$ yaitu sebesar 729,135 > 3,16. Dengan demikian dapat disimpulkan bahwa terdapat hubungan yang erat antara variabel jumlah produk $\left(X_{1}\right)$ dan biaya tenaga kerja $\left(X_{2}\right)$ terhadap laba $(Y)$ menggunakan $\alpha=0,025$ dan jumlah produk mempunyai korelasi paling besar, sehingga hipotesis pada UD. Mardlotillah Salty Egg yang menyatakan bahwa variabel jumlah produk $\left(X_{1}\right)$ mempunyai pengaruh paling dominan dibandingkan dengan variabel biaya tenaga kerja $\left(X_{2}\right)$ terbukti.
\end{abstract}

Kata Kunci : Jumlah Produk, Biaya Tenaga Kerja, dan Laba Usaha 


\section{PENDAHULUAN}

Usaha telur asin merupakan suatu usaha produktif di sektor peternakan baik untuk mata pencaharian utama maupun usaha sampingan. Sebagai salah satu usaha ekonomi, maka usaha usaha telur asin dikategorikan ke dalam usaha industri kecil atau usaha yang berskala kecil. Sektor industri telur asin menjadi tumpuan harapan bagi masyarakat Desa Bambang karena sebagian besar penduduknya peternak itik. Keberadaan suatu industri di suatu wilayah tentu akan mempengaruhi kondisi sosial ekonomi dengan penyerapan tenaga kerja dari masyarakat sekitarnya. Penyerapan tenaga kerja merupakan jumlah tertentu dari tenaga kerja yang digunakan dalam suatu unit usaha tertentu. Secara tidak langsung akan meningkatkan kesejahteraan dengan memberikan upah terhadap pekerjanya yang berasal dari pendapatan hasil industri tersebut.

$$
\text { Peluang usaha untuk }
$$

pembudidayaan bebek petelur dan kemudian dimaksimalkan menjadi industri telur asin sangatlah potensial. Hal tersebut dikarenakan setiap tahun permintaan telur asin semakin meningkat. Tiga puluh tahun terakhir pengembangan di bidang non pertanian ditingkatkan sebagai upaya memacu perekonomian Negara. Hal inilah yang berimbas pada kebijakan pembangunan nasional yang dilakukan di Indonesia berusaha umtuk meningkatkan laju pertumbuhan di sektor industri, sehingga diharapkan adanya keseimbangan antara sektor peternakan dan sektor industri. Selama ini, industrialisasi sering dianggap sebagai pintu masuk untuk membawa masyarakat kearah kemakmuran, paling tidak sebagai 'motor' penggerak dalam pembangunan ekonomi. Oleh karena itu, pengembangan industri menjadi perhatian pemerintah. Hal tersebut juga menyita perhatian pemerintah daerah untuk melakukan pengembangan ekonomi dalam mengubah kegiatan pembangunan dan peningkatan ekonomi di daerah.

Pembangunan yang menerpa pedesaan ini akhirnya memunculkan arus industrialisasi di pedesaan. Industri di dalam pedesaan sendiri mencakup industri yang muncul dari warga setempat (inovasi) maupun industri yang dipenetrasikan dari wilayah lain, seperti halnya industri telur asin yang akan peneliti bahas dalam skripsi ini. Harapan pemerintah adalah pertumbuhan ekonomi yang signifikan. Hal tersebut ditunjukkan dengan peningkatan kesejahteraan masyarakat. Ketersediaan sarana infrastruktur, peningkatan kualitas sumber daya manusia pemacu sektor ekonomi informal, dan sampai pada mencegah arus urbanisasi penduduk ke kota karena permasalahan kepadatan penduduk di kota-kota besar.

Desa Bambang Kecamatan Turi Kabupaten Lamongan yang menjadi studi kasus penelitian ini, telah berdiri industri telur asin sejak tahun 2006. Semenjak itu kehadiran industri tersebut tentu membawa beragam perubahan pada kondisi sosial ekonomi masyarakat serta lingkungan disana.

Kelompok UD. Mardlotillah Salty Egg merupakan badan usaha kelompok ternak itik yang didirikan pada tanggal 21 Maret 2006. Berawal dari ide dan gagasan kelompok dari ibuibu PKK, ide itu muncul karena Desa Bambang masyarakatnya sebagian besar merupakan peternak itik, di 
kelompok ternak itulah juga memproduksi telur asin. Usaha tersebut berkembang pada tahun 2007, yang bermula hanya 4 orang yang mendapatkan bantuan dari pemerintah 200 ekor itik, pakan, perlengkapan kandang, dll. Sebuah kelompok ternak rakyat yang mampu mengembangkan bisnisnya dari hulu hingga hilir. Para peternak itik sukses ternyata bukan peternak itik modern. Rata-rata anggota kelompok ternak rakyat adalah ibu-ibu petani.

Oleh karenanya, menarik untuk dikaji lebih dalam bagaimana kondisi masyarakat sekarang setelah adanya industri telur asin khususnya di Desa Bambang, maka penulis berdasarkan latar belakang tersebut diatas maka penulis mengambil judul penelitian "PENGARUH FAKTOR JUMLAH PRODUKSI DAN BIAYA TENAGA KERJA TERHADAP LABA USAHA TELUR ASIN UD. MARDLOTILLAH SALTY EGG DESA BAMBANG KEC. TURI KAB. LAMONGAN"

Berdasarkan latar belakang tersebut diatas maka dapat dirumuskan masalah sebagai berikut: Apakah jumlah produksi dan biaya tenaga kerja berpengaruh secara parsial terhadap laba usaha telur asin UD. Mardlotillah Salty Egg Desa Bambang Kec. Turi Kab. Lamongan, Apakah jumlah produksi dan biaya tenaga kerja berpengaruh secara simultan terhadap laba usaha telur asin UD. Mardlotillah Salty Egg Desa Bambang Kec. Turi Kab. Lamongan, Variabel manakah diantara jumlah produksi dan biaya tenaga kerja yang lebih dominan berpengaruh terhadap laba usaha telur asin UD. Mardlotillah Salty Egg Desa Bambang Kec. Turi Kab. Lamongan.
Tujuan penelitian ini adalah Untuk mengetahui pengaruh secara parsial jumlah produksi dan biaya tenaga kerja terhadap laba usaha telur asin UD. Mardlotillah Salty Egg Desa Bambang Kec. Turi Kab. Lamongan, untuk mengetahui pengaruh secara simultan jumlah produksi dan biaya tenaga kerja terhadap laba usaha telur asin UD. Mardlotillah Salty Egg Desa Bambang Kec. Turi Kab. Lamongan, untuk mengetahui variabel yang lebih dominan berpengaruh diantara jumlah produksi dan biaya tenaga kerja terhadap laba usaha telur asin UD. Mardlotillah Salty Egg Desa Bambang Kec. Turi Kab. Lamongan.

Pengertian UMKM Usaha Kecil Menengah (UKM) UU No. 20 Tahun 2008 terbagi dalam dua pengertian yakni : a). Industri Kecil adalah kegiatan ekonomi produktif yang berdiri sendiri, yang dilakukan oleh orang perorangan atau badan usaha yang bukan merupakan anak perusahaan atau bukan cabang perusahaan yang dimiliki, dikuasai, atau menjadi bagian baik langsung maupun tidak langsung dari Usaha Menengah atau Usaha Besar yang memiliki kekayaan bersih lebih dari Rp50.000.000,00 (lima puluh juta rupiah) sampai dengan paling banyak Rp500.000.000,00 (lima ratus juta rupiah) tidak termasuk tanah dan bangunan tempat usaha; atau memiliki hasil penjualan tahunan lebih dari Rp300.000.000,00 (tiga ratus juta rupiah) sampai dengan paling banyak Rp2.500.000.000,00 (dua milyar lima ratus juta rupiah). b). Usaha Menengah adalah entitas usaha yang memiliki kekayaan bersih lebih dari Rp. 500.000.000,00 (lima ratus juta rupiah) sampai dengan paling banyak Rp. 10.000.000.000,00 (sepuluh milyar 
rupiah) tidak termasuk tanah dan bangunan tempat usaha, serta memiliki hasil penjualan tahunan lebih dari $\mathrm{Rp}$. 2.500.000.000,00 (dua milyar lima ratus juta rupiah) sampai dengan paling banyak Rp.50.000.000.000,00 (lima puluh milyar rupiah).

Pengertian dan Klasifikasi Industri. Menurut Dumairy (2000:227). Industri mempunyai dua arti. Pertama, industri dapat berarti himpunan perusahaan-perusahaan sejenis. Kedua, industri dapat pula merujuk ke suatu sektor ekonomi yang di dalamnya terdapat kegiatan produktif yang mengolah bahan mentah menjadi barang jadi. Penggolongan industri dengan pendekatan besar kecilnya skala usaha dilakukan oleh beberapa lembaga. BPS mengklasifikasikan industri berdasarkan jumlah tenaga kerja per unit usaha, yaitu: (1) Industri Besar adalah industri yang mempunyai pekerja 100 orang atau lebih. Ciri industri besar adalah memiliki modal besar yang dihimpun secara kolektif dalam bentuk pemilikan saham, tenaga kerja harus memiliki keterampilan khusus, dan pimpinan perusahaan dipilih melalui seleksi.Misalnya: industri manufaktur. (2) Industri Menengah adalah industri yang mempunyai pekerja 20-99 orang. Ciri industri menengah adalah memiliki modal yang cukup besar, tenaga kerja memiliki keterampilan tertentu, dan pimpinan perusahaan memiliki kemampuan manajerial tertentu. Misalnya: industri konveksi, industri bordir, industri keramik. (3) Industri Kecil adalah industri yang mempunyai pekerja 5-19 orang. Ciri industri kecil memiliki modal yang relatif kecil, tenaga kerjanya berasal dari lingkungan sekitar atau masih ada hubungan saudara. Misalnya: industri genteng, industri batu bata, dan industri pengolahan rotan. (4) Industri Rumah Tangga adalah industri yang mempunyai pekerja 1-4 orang. Ciri industri ini memiliki modal yang sangat terbatas, tenaga kerja berasal dari anggota keluarga, dan pemilik atau pengelola industri biasanya kepala rumah tangga itu sendiri atau anggota keluarganya. Misalnya: industri anyaman, industri kerajinan, industri tahu/tempe, dan industri makanan ringan.

Menurut Murti Sumarni - John Soeprihanto (2010:205) Produksi adalah semua kegiatan untuk menciptakan dan menambah kegunaan suatu barang atau jasa, dengan memanfaatkan faktorfaktor produksi yang tersedia. Sedangkan proses produksi adalah cara, metode atau teknik untuk menciptakan atau menambah kegunaan suatu barang atau jasa dengan menggunakan faktorfaktor produksi yang ada. Faktor produksi terbagi menjadi 3 bagian yaitu: (a). Biaya Bahan Baku, yaitu besarnya nilai bahan baku yang dimasukkan ke dalam proses produksi untuk diubah menjadi barang jadi. (b). Biaya Tenaga Kerja, yaitu besarnya biaya yang terjadi untuk menggunakan tenaga karyawan untuk mengerjakan proses produksi. (c). Biaya Overhead Pabrik, yaitu biayabiaya yang tidak dapat digolongkan ke dalam biaya bahan baku maupun biayabiaya tenaga kerja. Menurut Mulyadi (2009:319). Pemilahan Pola Produksi. Penentuan jumlah produksi di dalam perencanaan produk harus diikuti dengan penetapan pola produksi untuk periode yang bersangkutan; sebab penjualan perusahaan berbeda-beda pada setiap bulannya. Oleh karenanya ada 3 (tiga) pilihan untuk melayani penjualan tersebut: Stabilitas Produksi 
dengan cara ini pola produksi ditetapkan stabil (tidak berubah-ubah) dari waktu ke waktu. Fluktuasi penjualan akan ditutup dengan persediaan produk akhir. Stabilitas Persediaan Akhir yaitu jumlah persediaan akhir ditentukan sama dari waktu ke waktu Fluktuasi penjualan langsung ditutup oleh produksi perusahaan. Oleh karena itu produksi akan berfluktuasi sesuai dengan jumlah penjualan. Produksi dan Persediaan akhir tidak stabil yakni Metode ini mengikuti fluktuasi penjualan, baik dalam produksinya maupun dalam persediaannya. Dengan ini diharapkan dapat mengurangi fluktuasi penjualan, karena pengaruhnya sebagian masuk pada persediaan produk akhir. Manajemen Produksi Adalah kegiatan untuk mengatur agar dapat menciptakan dan menambah kegunaan suatu barang atau jasa. Untuk mengatur ini perlu dibuat keputusan-keputusan yang berhubungan dengan usaha-usaha untuk mencapai tujuan agar barang atau jasa yang akan dihasilkan sesuai dengan yang direncanakan.

Biaya tenaga kerja adalah harga yang dibebankan untuk penggunaan tenaga kerja manusia tersebut. Penggolongan menurut fungsi pokok dalam organisasi perusahaan. Organisasi dalam perusahaan manufaktur dibagi kedalam tiga fungsi pokok: produksi, pemasaran, dan administrasi. Oleh karena itu perlu ada penggolongan dan perbedaan antara tenaga kerja pabrik dan nonpabrik. Pembagian ini bertujuan untuk membedakan biaya tenaga kerja yang merupakan unsur harga pokok produk dari biaya tenaga kerja nonpabrik, yang bukan unsure harga pokok produksi, melainkan merupakan unsure biaya usaha. Dengan demikian, biaya tenaga kerja perusahaan manufaktur digolongkan menjadi: biaya tenaga kerja produksi, biaya tenaga kerja pemasaran, dan biaya tenaga kerja administrasi \& umum.

Menurut Soemarso S.R (2002:227) Laba usaha adalah laba yang diperoleh semata-mata dari kegiatan utama perusahaan. Konsep laba tersebut adalah: (a). Psychic income, yang menunjukkan konsumsi barang/jasa yang dapat memenuhi kepuasan dan keinginan individu. (b). Real income, yang menunjukkan kenaikan dalam kemakmuran ekonomi yang ditunjukkan oleh kenaikan cost of living. (c). Money income, yang menunjukkan kenaikan nilai moneter suber-sumber ekonomi yang digunakan untuk konsumsi sesuai biaya hidup cost of living. Jenis-jenis Laba adalah sebagai berikut: (1) Risk Bearing Theory of Profit yakni Perusahaan harus mempertahankan keuntugan di atas normal (laba ekonomis) apabila jenis usahanya mempunyai resiko yang sangat tinggi. Contoh : pengeboran minyak lepas pantai. (2) Frictional Theory of Profit asumsinya pasar sering berada dalam posisi disequilibrium. Akibatnya perusahaan tidak pernah mendapat laba diatas normal melainkan laba normal saja. (3) Monopoly Theory of Profit yakni Perusahaan dapat mempertahankan laba diatas normal dalam jangka panjang apabila perusahaan tersebut dapat memperoleh fasilitas dari pemerintah, hak paten, dapat mencapai skala ekonomis, dan lain-lain (4) Innovation Theory of Profit yakni Perusahaan dapat memperoleh laba diatas normal apabila ia dapat mencapai penemuan-penemuan baru. (5) Managerial Efficiency Theory of Profit / Compensatory Top yakni suatu perusahaan dapat mencapai laba di atas 
normal apabila ia berhasil melakukan efisiensi di berbagai bidang serta dapat memenuhi keinginan konsumennya.

Hubungan antara jumlah produksi dan biaya tenaga kerja terhadap laba adalah jumlah produksi akan berpengaruh terhadap volume penjualan apabila suatu perusahaan mampu menjual hasil produksi dengan jumlah yang besar, maka suatu perusahaan akan memperoleh laba yang besar pula. Sedangkan biaya tenaga kerja juga akan berpengaruh terhadap laba, dimana semakin besar biaya yang dikeluarkan maka semakin sedikit laba yang diperoleh. Sebaliknya semakin sedikit biaya yang dikeluarkan maka semakin besar laba yang diperoleh.

\section{METODE PENELITIAN}

Waktu Penelitian ini dilaksanakan pada awal Bulan Januari 2016 sampai dengan Bulan Juni 2016. Penelitian dilaksanakan di Desa Bambang, Kecamatan Turi, Kabupaten Lamongan. Lokasi penelitian ini merupakan tempat dimana peneliti melakukan penelitian untuk memperoleh data-data yang diperlukan. Adapun penelitian ini dilaksanakan di industri telur asin UD. Mardlotillah Salty Egg Desa Bambang, Kecamatan Turi, Kabupaten Lamongan.

Jenis penelitian yang digunakan dalam penelitian ini adalah bersifat (a). Deskriptif adalah suatu metode dalam meneliti status sekelompok manusia, suatu objek, suatu set kondisi, suatu system pemikiran, ataupun suatu kelas peristiwa pada masa sekarang. (Moh Nazir, 2014:43). (b). Kuantitatif adalah suatu proses menemukan pengetahuan yang menggunakan data berupa angka sebagai alat menganalisis keterangan mengenai apa yang ingin kita ketahui. (Kasiram, 2008:149) (c) Eksploratif adalah salah satu jenis penelitian sosial yang tujuannya untuk memberikan sedikit definisi atau penjelasan mengenai konsep atau pola yang digunakan dalam penelitian. (Mantra Ida Bagus, 2004:37)

Dalam penelitian ini adalah data perusahaan UD. Mardlotillah Salty Egg Lamongan. Dari rencana penelitian diatas teknik penarikan sampelnya adalah menggunakan populasi tetapi dalam waktu menggunakan sampelnya adalah data Industri Telur Asin UD. Mardlotillah Salty Egg Lamongan yang berdasarkan data keuangan tahun 20112015

Adapun teknik pengambilan data dari penelitian ini adalah (a).Observasi dilakukan untuk memperoleh informasi tentang kelakuan manusia seperti yang terjadi dalam kenyataan. Dengan metode observasi ini peneliti dapat memperoleh gambaran yang lebih jelas dalam mengumpulkan data. (b). Wawancara Yaitu sebuah dialog yang dilakukan oleh pewawancara untuk memperoleh informasi dari terwawancara atau interviuwer (c) Dokumentasi Asal kata dokumen berarti barang-barang tertulis. Didalam melaksanakan metode dokumentasi, peneliti menyelidiki benda-benda tertilis seperti buku-buku, majalah, dokumen, peraturan-peraturan

Operasional variabel adalah hal-hal yang menjadi obyek penelitian yang di tetapkan dalam suatu kegiatan penelitian yang menunjukan variasi atau dapat berubah-ubah baik secara kuantitatif maupun kualitatif (Suharsimi arikunto, 2013;17). Sesuai dengan judul dan pembahasan yang terjadi, maka penulis mendefinisikan tentang variabel yang 
akan diteliti adalah sebagai berikut : (a) Variabel Bebas/Independen Variabel (X) adalah variabel yang mempengaruhi atau yang menjadi sebab perubahanya atau timbulnya variabel dependen (Suharsimi arikunto, 2013;162). Dalam penelitian ini yang menjadi variabel bebas adalah Produksi $\left(\mathrm{X}_{1}\right)$ dan biaya tenaga kerja $\left(\mathrm{X}_{2}\right)$.Variabel Terikat /Dependen Variabel (Y) adalah variabel yang dipengaruhi atau yang menjadi akibat, karena adanya variabel bebas (Suharsimi arikunto, 2013;162) Dalam penelitian ini variabel terikat adalah laba usaha. Laba usaha adalah laba yang diperoleh semata-mata dari kegiatan utama perusahaan (Soemarso S.R,2002:227).

Metode analisis yang digunakan adalah Uji Korelasi Parsial, Regresi Linier Berganda, Korelasi Linier Berganda, Koefisien Determinasi, Uji t dan Uji F.

\section{HASIL PENELITIAN DAN PEMBAHASAN}

Dari pembahasan diatas maka diperoleh hasil sebagai berikut : (1) Hasil Persamaan secara Parsial sebagai berikut : (a) Korelasi Parsial Koefisien korelasi parsial antara laba dan jumlah produk $\mathrm{r}_{\mathrm{x} 1 \mathrm{y}}$ adalah 0,977. Kekuatan hubungan antara laba dan jumlah produk ketika variabel lainnya konstan adalah sangat kuat. Koefisien korelasi parsial antara laba dan biaya tenaga kerja $r_{x 2 y}$ adalah 0,973. Kekuatan hubungan antara laba dan biaya tenaga kerja ketika variabel lainnya konstan adalah sangat kuat. (b) Uji t ${ }_{1}$ (jumlah produk terhadap laba) sebesar $35,151>2,00172$. Uji $t_{2}$ (biaya tenaga kerja terhadap laba) sebesar 32,390 > 2,00172 . Karena $t_{\text {hitung }}$ lebih besar dari $t$ tabel dan probabilitasnya lebih kecil dari
5\%, maka $\mathrm{H}_{0}$ ditolak, berarti variabel jumlah produk $\left(\mathrm{X}_{1}\right)$ dan biaya tenaga kerja $\left(\mathrm{X}_{2}\right)$ secara parsial mempunyai pengaruh signifikan terhadap laba $(\mathrm{Y})$. Dengan demikian dapat disimpulkan jumlah produk mempunyai korelasi paling besar, sehingga hipotesis pada UD. Mardlotillah Salty Egg yang menyatakan bahwa variabel jumlah produk $\left(\mathrm{X}_{1}\right)$ mempunyai pengaruh paling dominan dibandingkan dengan variabel biaya tenaga kerja $\left(\mathrm{X}_{2}\right)$ terbukti.

Hasil Persamaan secara Simultan adalah (a) Korelasi Berganda (R) Dari hasil analisis korelasi berganda menunjukkan bahwa hubungan antara variabel terikat $(Y)$ yaitu laba pada UD. Mardlotillah Salty Egg dengan variabel bebas $\left(\mathrm{X}_{1}\right)$ jumlah produk dan $\left(\mathrm{X}_{2}\right)$ biaya tenaga kerja secara simultan adalah sebesar 0,981 atau $98,1 \%$. Hasil ini menunjukkan bahwa hubungan yang terjadi antara variabel terikat (dependen) dengan variabel bebas (independen) sangat kuat. (b) Koefisien Determinasi Hasil analisis uji koefisien determinasinya adalah 0,9623. Angka ini menunjukkan bahwa jumlah produk dan biaya tenaga kerja memberikan pengaruh terhadap laba sebesar $96,23 \%$ dan sisanya dipengaruhi oleh variabel lain yang tidak diteliti. (c) Uji F Dari hasil penelitian nilai signifikan $F$ sebesar $0,000<0,05(5 \%)$ dan $\mathrm{F}_{\text {hitung }}$ lebih besar dari $F_{\text {tabel }}$ yaitu sebesar $729,135>3,16$. Karena $F_{\text {hitung }} 729,135>$ $\mathrm{F}_{\text {tabel }}$ 3,16 maka $\mathrm{H}_{0}$ ditolak dan $\mathrm{Ha}$ diterima sehingga variabel jumlah produk dan biaya tenaga kerja bersamasama memiliki pengaruh signifikan terhadap laba.

(3) Regresi Linier Berganda. Berdasarkan persamaan regresi linier berganda didapatkan data sebagai 
berikut : $Y=2,623+0,723 X_{1}+0,354$ $\mathrm{X}_{2}$. Analisis atas hasil analisis tersebut dapat dinyatakan sebagai berikut : $($ a $)=$ 2,623 Artinya laba rata-rata adalah sebesar 2,623 bila jumlah produk dan biaya tenaga kerja tidak mengalami perubahan atau konstan. (b) $b_{1}=0,723$ Jika terjadi kenaikan sebesar 1 satuan pada variabel jumlah produk $\left(\mathrm{X}_{1}\right)$, sedangkan biaya tenaga kerja $\left(\mathrm{X}_{2}\right)$ konstan, maka laba naik sebesar 0,723 (c) $b_{2}=0,354$ Jika terjadi kenaikan sebesar 1 satuan pada variabel biaya tenaga kerja $\left(\mathrm{X}_{2}\right)$, sedangkan jumlah produk $\left(\mathrm{X}_{1}\right)$ konstan, maka laba naik sebesar 0,354. Seingga dapat diartikan bahwa variabel $\mathrm{X}_{1}$ jumlah produk berpengaruh secara dominan terhadap laba. Hal ini dapat dibuktikan dengan Y $=2,623+0,723 X_{1}+0,354 X_{2}$

\section{KESIMPULAN DAN SARAN}

\section{KESIMPULAN}

Berdasarkan hasil penelitian dan pembahasan maka dapat dinyatakan koefisien korelasi parsial antara laba dan jumlah produk adalah 0,977. Kekuatan hubungan antara laba dan jumlah produk ketika variabel lainnya konstan adalah sangat kuat koefisien korelasi parsial antara laba dan biaya tenaga kerja adalah 0,973. Variabel jumlah produk $\left(\mathrm{X}_{1}\right)$ secara parsial mempunyai pengaruh signifikan terhadap laba $(\mathrm{Y})$ dengan $\mathrm{t}$ hitung untuk variabel jumlah produk lebih besar dari $\mathrm{t}$ tabel yaitu sebesar 35,151>2,00172. variabel biaya tenaga kerja $\left(\mathrm{X}_{2}\right)$ secara parsial mempunyai pengaruh signifikan terhadap laba $(\mathrm{Y})$ dengan $\mathrm{t}$ hitung untuk variabel biaya tenaga kerja lebih besar dari $\mathrm{t}$ tabel yaitu sebesar 32,390 > 2,00172. Variabel jumlah produk dan biaya tenaga kerja secara simultan berpengaruh signifikan terhadap laba dan $F_{\text {hitung }}$ lebih besar dari $F_{\text {tabel }}$ yaitu sebesar 729,135 > 3,16.

Dengan demikian dapat disimpulkan bahwa terdapat hubungan yang erat antara variabel jumlah produk $\left(\mathrm{X}_{1}\right)$ dan biaya tenaga kerja $\left(\mathrm{X}_{2}\right)$ terhadap laba (Y) menggunakan $\alpha=$ 0,025 dan jumlah produk mempunyai korelasi paling besar, sehingga hipotesis pada UD. Mardlotillah Salty Egg yang menyatakan bahwa variabel jumlah produk $\left(\mathrm{X}_{1}\right)$ mempunyai pengaruh paling dominan dibandingkan dengan variabel biaya tenaga kerja $\left(\mathrm{X}_{2}\right)$ terbukti.

\section{SARAN}

Berdasarkan kesimpulan diatas maka saran-saran yang dapat penulis sampaikan adalah sebagai berikut: Diharapkan UD. Mardlotillah Salty Egg dapat meningkatkan jumlah produksi sesuai kebutuhan konsumen, sehingga konsumen merasa puas karena ketersediaan produksi UD. Mardlotillah Salty Egg untuk kebutuhan di bidang makanan yang akan meningkatkan laba perusahaan. Diharapkan UD. Mardlotillah Salty Egg menambah biaya tenaga kerja, meningkatkan kualitas Sumber Daya Manusia dan peralatan yang modern sehingga produksi dapat ditingkatkan. Hendaknya pihak UD. Mardlotillah Salty Egg terus menjaga fasilitas fisik dalam seperti kondisi ruangan produksi yang steril perlu ditingkatkan lagi.serta sarana yang mudah dijangkau oleh konsumen 


\section{DAFTAR PUSTAKA}

Arikunto, Suharsimi. 2013. Prosedur Penelitian, Suatu Pendekatan Praktik. Jakarta: PT Rineka Cipta

Amaliya, Novita. 2014. Pengaruh Adanya Industri Kerajinan Songkok Terhadap Tingkat Pendapatan Masyarakat Desa Bojoasri Kecamatan Kalitengah Kab. Lamongan. Lamongan. Skripsi. Universitas Islam Lamongan

Dumairy, 1999. Perekonomian Indonesia. Jakarta: PT Gelora Aksara Pratama

Kasiram, 2008. Metodologi Penelitian Kualitatif-Kuntitatif. Malang: UINMalang Press

Khanifah, Susi. 2011. Analisis Industri Kecil Tenun Terhadap Penyerapan Tenaga Kerja dan Pendapatan Masyarakat Desa Parengan Kecamatan Maduran Kabupaten Lamongan. Lamongan. Skripsi. Universitas Islam Lamongan

Kuncoro, Mudrajad. 2009. Ekonomika Indonesia Dinamika Lingkungan Bisnis di Tengah Krisis Global. Yogyakarta: UPP STIM YKPN

Mulyadi, 2014. Akuntansi Biaya. Yogyakarta: YKPN

Nazir, Moh. 2013. Metode Penelitian. Bogor: Ghalia Indonesia

Soemarso S.R. 1996. Akuntansi Suatu Pengantar. Jakarta: PT Rineka Cipta Sudjana, 2005. Metoda Statistika. Bandung: Tarsito

Sumarni, Murti, 2005. Pengantar Bisnis. Yogyakarta: Liberty Yogyakarta
Sukirno, Sadono, 2013, Makroekonomi Teori Pengantar, Jakarta: Rajawali Pers Riahi, Ahmed, 2011. Theory Accounting. Jakarta: Salemba Emp 